\title{
Pemanfaatan Bahan Ajar Berwawasan Lingkungan Pada Mata Pelajaran Fisika Di SMK Negeri 4 Jeneponto
}

\author{
Alamsyah ${ }^{1 *}$, Risma Haris ${ }^{2}$ \\ ${ }^{1}$ Program Studi PKLH Pascasarjana Universitas Negeri Makassar \\ "Email: Alamsyaharif20@ gmail.com \\ ${ }^{2}$ Program Studi Kesehatan Masyarakat Pascasarjana Universitas Indonesia Timur
}

\begin{abstract}
(C) 2019 - UEJ Program Studi Pendidikan Kependudukan dan Lingkungan Hidup Universitas Negeri Makassar. Ini adalah artikel dengan akses terbuka dibawah Licensi CC BY-NC-4.0

(https://creativecommons.org/licenses/by-nc/4.0/ )
\end{abstract}

\begin{abstract}
ABSTRAK
Sekolah sebagai institusi pendidikan merupakan salah satu target utama yang dilibatkan Penelitian ini dilaksanakan untuk mengetahui pemanfaatan bahan ajar berwawasan lingkungan dapat meningkatkan sikap dan pengetahuan lingkungan peserta didik pada mata pelajaran fisika pokok bahasan usaha, energi, daya, dan efisiensi. Pelaksanaan pengembangan bahan ajar berwawasan lingkungan dan perlakuan dalam proses penelitian ini dilaksanakan di SMK Negeri 4 Jeneponto. Penelitian ini termasuk penelitian kuantitatif yang bersifat pengembangan dengan desain yang digunakan dalam penelitian ini adalah One Group Pretest-Posttest Design.Hasil penelitian ini menunjukkan penggunaan bahan ajar berwawasan lingkungan dapat meningkatkan sikap dan pengetahuan lingkungan peserta didik dari sebelum perlakuan (treatment) dilaksanakan. Perolehan nilai rata-rata sikap lingkungan adalah 73.8 dengan skor indeks $N$-gain yaitu 0.4 berada dalam kategori sedang. Penilaian pengetahuan lingkungan peserta didik juga mengalami peningkatan dengan nilai rata-rata sebesar 77.1 dan indeks $N$-gain 0.5 dalam kategori sedang.
\end{abstract}

Kata kunci: bahan ajar berwawasan lingkungan, sikap lingkungan, pengetahuan lingkungan.

\begin{abstract}
ABSTRAC.
This research was conducted to find out the use of environmentally sound teaching materials can improve the attitude and knowledge of the environment of students in physics subjects the subject matter of business, energy, power, and efficiency. The implementation of the development of environmentally sound teaching materials and treatment in the research process was carried out at SMK Negeri 4 Jeneponto. This study includes the development of quantitative research with the design used in this study is One Group Pretest-Posttest Design. The results of this study indicate the use of environmentally friendly teaching materials can improve the attitude and knowledge of the environment of students from before treatment (treatment) is done. The average score for environmental attitudes is 73.8 with a $N$-gain index score of 0.4 in the medium category. The assessment of students' environmental knowledge also increases with an average value of 77.1 and an $\mathrm{N}$-gain index of 0.5 in the medium category.
\end{abstract}

Keywords: environmentally friendly teaching materials, environmental attitudes, environmental knowledge. 
UNM Environmental Journals, Vol. 2 No. 2 April hal. 28-33

\section{PENDAHULUAN}

Undang-Undang Nomor 20 tahun 2003 tentang Sistem Pendidikan Nasional Pasal 3 menegaskan bahwa pendidikan nasional berfungsi mengembangkan kemampuan dan membentuk watak serta peradaban bangsa yang bermartabat dalam rangka mencerdaskan kehidupan bangsa, bertujuan untuk berkembangnya potensi peserta didik agar menjadi manusia yang beriman dan bertakwa kepada Tuhan Yang Maha Esa, berakhlak mulia, sehat, berilmu, cakap, kreatif, mandiri, dan menjadi warga negara yang demokratis serta bertanggungjawab. Berdasarkan pandangan tersebut, dapat dikatakan bahwa pendidikan yang mampu mendukung pembangunan di masa yang akan datang adalah pendidikan yang mampu mengembangkan potensi peserta didik, sehingga yang bersangkutan berani menghadapi, mampu memecahkan, dan berhasil mengatasi masalah kehidupan yang dihadapinya. Oleh karena itu, pendidikan harus menyentuh potensi nurani maupun potensi kompetensi peserta didik.

Pemikiran ini mengandung konsekuensi bahwa penyempurnaan atau perbaikan pendidikan menengah kejuruan untuk mengantisipasi kebutuhan dan tantangan masa depan perlu terus-menerus dilakukan, diselaraskan dengan perkembangan kebutuhan dunia usaha/dunia industri, perkembangan dunia kerja, serta perkembangan ilmu pengetahuan, teknologi, seni, dan bisnis. Salah satu upaya pemerintah untuk meningkatkan mutu pendidikan ialah dengan cara pengembangan kurikulum, dimana kurikulum merupakan sebuah sarana atau alat dalam pelaksanaan proses belajar mengajar. Kunci utama untuk mencapai keberhasilan tujuan sekolah terletak pada kurikulum, yang merupakan jantung dalam proses pendidikan.

Permendikbud nomor 103 tahun 2014 yang diperbaharui dengan Permendikbud nomor 22 tahun 2016 secara tegas memberikan uraian dasar tentang proses pembelajaran yang semestinya menjadi acuan dalam pelaksanaan pembelajaran pada tingkat sekolah menengah. Permendikbud tersebut diawali dengan definisi pembelajaran sebagai proses interaksi antarpeserta didik dan antara peserta didik dengan pendidik dan sumber belajar pada suatu lingkungan belajar. Selain itu, proses pembelajaran yang dilaksanakan di dalam kelas mesti interaktif, menyenangkan, menantang, inspiratif, memotivasi peserta didik untuk berpartisipasi aktif, serta memberikan ruang yang cukup bagi prakarsa, kreativitas, dan kemandirian sesuai dengan bakat, minat, kemampuan, dan perkembangan fisik serta psikologis peserta didik. Perubahan paradigma pendidikan dari teacher centered menjadi student centered memberikan konsekuensi diantaranya terhadap cara pandang kita terhadap peserta didik.

Kurikulum 2013 menitikberatkan pada pendekatan saintifik atau pendekatan berbasis proses keilmuan. Proses pembelajaran yang dilakukan harus memberikan pengalaman belajar 5M terhadap peserta didik. Lima (5) M tersebut adalah: mengamati, menanya, mengumpulkan informasi/mencoba, menalar/ mengasosiasi, dan mengkomunikasikan. Kemampuan 5M tersebut diatas sebenarnya berakar pada keterampilan proses sains yang telah lama dikenal dalam pembelajaran sains/IPA termasuk di dalamya mata pelajaran fisika. Konteks Pembelajaran fisika memungkinkan pemanfaatan lingkungan fisik (alam) dilakukan untuk mengkaji fenomena atau gejala alam terkait dengan konsep dan prinsip fisika, serta lingkungan fisik maupun sosial dapat dimanfaatkan untuk mengkaji penerapan (konsep atau prinsip fisika) yang baik secara langsung maupun tidak langsung dimanfaatkan masyarakat dalam beraktivitas dan berinteraksi sosial (Arifuddin, M., Salam,M., dan Shofa Mawaddah; 2017).

Pembelajaran fisika di SMK bukan hanya kumpulan pengetahuan yang berupa fakta-fakta, konsep-konsep, atau prinsip-prinsip ilmu fisika tetapi merupakan suatu proses aplikasi teori keilmuan dengan proses alamiah serta interkasi komponen-komponen lingkungan, apabila diintegrasikan dapat menjadi suatu kajian pembelajaran ilmu fisika yang beroarientasi kelingkungan (berwawasan lingkungan). Hal tersebut selaras dengan salah satu tujuan pembelajaran peserta didik di Sekolah Menengah Kejuruan (SMK) supaya tercipta sumber daya manusia yang kompeten serta terampil dalam mengolah sumber daya alam dalam kegiatan produksi di dunia usaha dunia indusri tetapi juga memiliki pengetahuan, sikap dan kepedulian terhadap kelestarian lingungan hidup.

Konsep tersebut pendidikan lingkungan hidup dapat secara terintegratif dilakukan dalam penyajian setiap mata pelajaran di Sekolah Menengah Kejuruan (SMK) termasuk di dalamnya mata pelajaran fisika. Standar kompetensi lulusan (SKL) dan kompetensi dasar (KD) mata pelajaran fisika jenjang SMK memungkinkan adanya keterpaduan antara konsep dasar obyek kajian ilmu fisika dengan konsep pengetahuan mengenai lingkungan hidup salah satunya pada pembahasan atau pokok bahasan usaha, energi, daya dan efisiensi. Aktualisasi implementasi upaya integratif mata pelajaran 


\section{Alamsyah, Pemanfaatan Bahan Ajar}

fisika di SMK dengan pengetahuan lingkungan hidup yaitu dengan membuat bahan ajar berupa modul (hand out) mata pelajaran fisika khususnya pokok bahasan usaha, energi, daya dan efisiensi yang disisipkan pengetahuan, nilai-nilai sikap, etika, norma lingkungan hidup sehingga muaranya (ouputnya) tersusun bahan ajar mata pelajaran fisika yang berwawasan lingkungan yang dapat digunakana dalam pembelajaran di SMK khusunya di Sekolah Menengah Kejuruan Negeri (SMKN) 4 Jeneponto yang merupakan tempat lokasi penelitian kami selaku peneliti.

Pelaksanaan kegiatan pembelajaran di SMK Negeri 4 Jeneponto berupaya memberikan pendidikan dan pelatihan kepada peserta didik untuk mampu serta terampil menguasai kompetensi sesuai bidang keahlianya secara kompleks. Penguasaan kompetensi secara kompleks bukan hanya semata penguasaan standar kemampuan peserta didik sesuai bidang atau paket keahlianya (jurusan) di SMK akan tetapi juga bagaimana kompetensi keahlian tersebut dipadukan atau dilengkapi dengan pengetahuan serta nilai sikap maupun keterampilan dari aspek bidang lainnya yang erat kaitanya seperti konsep sehingga dapat menghasilkan standar kompetensi yang lebih paripuna bagi peserta didik sebagai bekal mereka dalam meningkatkan kualitas sumber dayanya.

Salah satu komponen penting yang dapat dipadukan dan di integrasikan dalam kurikulum mata pelajaran di SMK Negeri 4 Jeneponto yaitu pendidikan lingkungan hidup hal ini sejalan dengan visi dari SMK Negeri 4 Jeneponto itu sendiri yaitu "menjadi lembaga pendidikan yang mampu menghasilkan tenaga kerja produktif, kreatif dan inovatif yang beriman dan bertaqwa serta berwawasan lingkungan". Penjabaran dari visi tersebut adanya kurikulum yang fleksibel dan adaptif yang beroreintasi pada lapangan kerja serta upaya menumbuhkan kesadaran, kepedulian, serta kecintaaan upaya-upaya pelestarian lingkungan hidup. Diharapkan setiap mata pelajaran terutama bidang sains fisika yang kajiannya berkaitan erat topik pembahasanya dengan konsep-konsep pengetahuan lingkungan dapat memadukan dua hal tersebut dalam bahan ajar dan perangkat pembelajarannya.

Di kesempatan kajian ini kami menyusun bahan ajar mata pelajaran fisika SMK pokok bahasan usaha, energi, daya dan efisiensi yang berwasasan lingkungan sehingga hasilnya dapat meningkat pengetahuan dan sikap terhadap lingkungan peserta didik di SMK Negeri 4 Jeneponto. Secara kongkrit bahan ajar mata pelajaran fisika kompetensi dasar usaha, energi, daya dan efisiensi kajian dan topik pembahasannya di padukan dengan pengetahuan lingkungan hidup mengenai arti pentingnya lingkungan dalam memberikan dukungan kepada makhluk hidup untuk melakukan usaha (kegiatan) serta memperoleh energi.

Hal lain yang penting diterangkan dalam kajian bahan ajar ini adalah pentingnya upaya penghematan energi yang berhubungan dengan pelestarian lingkungan hidup seiring dengan usaha pengembangan energi terbarukan yang lebih ramah lingkungan sehingga mengurangi pencemaran lingkungan. Setelah mempelajari konsep serta konteks dari bahan ajar tersebut peserta didik akan tumbuh wawasan pemahaman tentang sebuah usaha (kegiatan) yang didukung oleh adanya energi di yang tersedia di lingkungan serta perubahan-perubahannya dapat menjadi sebuah upaya berkelanjutan memenuhi kebutuhan aktivitas kehidupan makhluk hidup disertai upaya-upaya agar kesemuanya berkelanjutan dan lestari dilingkungan.

Selain pemahaman tersebut akan timbul pemikiran dan perhatian peserta didik bahwa aktivitas usaha, daya maupun pemanfaatan energi tidak dapat dipisahkan dengan upaya menjaga keselamatan dan kelestarian lingkungan hidup yang merupakan ruang yang mendukung dan menyediakan hal tersebut.

\section{METODE}

Penelitian ini termasuk penelitian kuantitatif yang bersifat pengembangan yang bertujuan untuk penyusunan bahan ajar berwawasan lingkungan mata pelajaran fisika khususnya untuk pokok bahasan usaha, energi, daya dan efisiensi sehingga dapat meningkatkan tingkat pemahaman pengetahuan dan sikap pada lingkungan peserta didik di SMK Negeri 4 Jeneponto. Desain yang digunakan dalam penelitian ini adalah One Group Pretest-Posttest Design. Bahan ajar yang dikembangkan meliputi modul mata pelajaran fisika SMK, sesuai standar kompetensi lulusan (SKL) kurikulum 2013 yang dipadukan atau diintegrasikan dengan konsep, teori, kajian serta isu-isu tentang lingkungan hidup. 
Modul pembelajaran tersebut diharapkan dapat meningkatkan pemahaman, pengetahuan serta sikap siswa terhadap pentingnya keberadaan dan kelestarian lingkungan hidup pada mata pelajaran fisika di SMK.

Kegiatan penelitian dan pengembangan ini dilakukan di SMK Negeri 4 Jeneponto. Subjek Penelitian ini adalah adalah peserta didik kelas X 1 bidang keahlian agribisnis tanaman pangan dan hortikultura (ATPH) 1 yang berjumlah 36 orang terdiri 24 orang perempuan dan 12 orang laki-laki.

Variabel yang diteliti dalam penelitian ini adalah peningkatan pengetahuan dan sikap lingkungan peserta didik dengan menggunakan bahan ajar berwawasan lingkungan pada mata pelajaran fisika SMK pokok bahasan usaha, energi, daya dan efisiensi,

Pengetahuan lingkungan merupakan pemahaman dari kajian hubungan manusia dengan lingkungannya dan dampaknya bagi kehidupan serta mengetahui arti penting menjaga kelestarian lingkungan. Pengetahuan lingkungan di teliti dengan menggunakan instrumen tes objektif dengan jawaban yang telah disediakan dalam bentuk benar dan salah (true false or yes-no)) mengenai internalisasi pemahaman lingkungan pada mata fisika pokok bahasan usaha, energi, daya dan efisiensi,

Sikap lingkungan dalam penelitian ini adalah kecenderungan peserta didik untuk berbuat atau bertindak dari pengaruh proses belajar mengajar mengenai aspek-aspek pentingnya keberadaan dan kelestarian lingkungan dengan menggunakan bahan ajar berwawasan lingkungan .Secara nyata sikap siswa ditandai dengan perasaan dan reaksi secara intelektual dan emosional dalam proses pembelajaran. Sikap lingkungan lingkungan siswa di ukur dan nilai dengan menggunakan angket/kuesioner bersifat tertutup yang berisi pilihan jawaban mengenai kecenderungan bertindak peserta didik terhadap pentingya keberadaan serta kelestarian lingkungan pada mata pelajaran fisika pokok bahasan usaha, energi, daya dan efisiensi,

Tahapan selanjutnya merekapitulasi skor hasil pengisian kuesioner sebelum dan sesudah perlakuan untuk mengetahui peningkatan sikap belajar siswa kemudian dimasukkan dalam kriteria sikap belajar siswa, sebagai berikut;

Tabel 1. Kriteria Penilaian Sikap Peserta Didik

\begin{tabular}{ccc}
\hline $\begin{array}{c}\text { Skor Peserta } \\
\text { Didik (siswa) }\end{array}$ & $\begin{array}{c}\text { Persentase } \\
(\%)\end{array}$ & $\begin{array}{c}\text { Kategori Nilai } \\
\text { Sikap }\end{array}$ \\
\hline $81-100$ & $76-100$ & Sangat tinggi \\
$61-80$ & $51-75$ & Tinggi \\
$41-60$ & $26-50$ & Rendah \\
$20-40$ & $0-25$ & Sangat rendah \\
\hline
\end{tabular}

Sumber: Berdasarkan Data Penelitian

Rancangan penelitian yang digunakan adalah One Group Pretest-Posttest Design. Langkah pertama adalah melakukan pengukuran berupa tes awal (pre test) untuk mengetahui kemampuan awal siswa mengenai pengetahuan dan sikap lingkungan pada mata pelajaran fisika khususnya pada pokok bahasan usaha, energi, daya dan efisiensi, Kemudian dikenakan perlakuan (treatment) dengan melaksanakan pembelajaran sebanyak 4 kali pertemuan di kelas dengan menggunakan bahan ajar yang terintegrasi dengan konsep, teori serta nilai-nilai lingkungan hidup (berwawasan lingkungan).

Tahapan selanjunya setelah diberikan perlakuan dalam proses pembelajaran adalah dilakukan tes akhir (post test) untuk mengetahui kemampuan peserta didik mengenai aspek pengetahuan dan sikap lingkungan yang berkaitan dengan bahan ajar yang telah di pelajari. Pengukuran dan penilaian lanjutan dilakukan untuk mengetahui sejauh mana pengaruh pemanfaatan bahan ajar yang berwawasan lingkungan terhadap tingkat pemahaman, pengetahuan dan sikap lingkungan peserta didik. Secara sederhana rancangan penelitian ini dapat digambarkan sebagai berikut:

$$
\text { pre test ---------------treatment------------- post test }
$$

Pengumpulan data dari penelitian ini dilaksanakan dengan melakukan tes pengetahuan dan sikap lingkungan siswa. Selanjutnya hasil pelaksanaan tes digunakan untuk mengetahui nilai 


\section{Alamsyah, Pemanfaatan Bahan Ajar}

pengetahuan dan sikap peserta didik sebelum dan sesudah perlakuan (treatment) yang menentukan sampai sejauh mana efektivitas penggunaan bahan ajar berwawasan lingkungan dengan metode gain score. Teknik analisis data dalam penelitian ini menggunakan analisis statistik deskriptif dengan membandingkan nilai pengetahuan dan sikap peserta didik sebelum perlakuan dan sesudah perlakuan. Jawaban yang diberikan peserta didik pada instrumen tes pengetahuan serta angket/ kuesioner sikap, di berikan skor tertentu dan dilakukan rekapitulasi skor hasil pengisian instrumen penelitian sebelum dan sesudah perlakuan selanjutnya secara statistik di hitung skor perolehan masing-masing peserta didik dan menentukan skor maksimum, skor minimum, nilai rata-rata, dan standar deviasi.

Data nilai pengetahuan dan sikap peserta didik sebelum dan sesudah perlakuan kemudian di hitung dengan nilai gain $\langle\mathrm{g}\rangle$ ternormalisasi. Uji normalitas gain adalah untuk memberikan gambaran umum peningkatan skor hasil pembelajaran dari aspek pengetahuan serta sikap peserta didik sebelum dan sesudah penggunaan bahan ajar berwawasan lingkungan. Dari perhitungan tersebut dapat dilihat selisih perbedaan skor kemampuan siswa/peserta didik, baik dalam bentuk peningkatan maupun penurunan, sehingga pengujian untuk menentukan ada tidaknya perkembangan.

Menerapkan uji N-gain ini dapat dilakukan dengan menggunakan rumus dibawah ini :

$$
\mathrm{g}=\frac{\text { Spost }- \text { Spre }}{\text { Smak }- \text { Spre }}
$$

Keterangan :

g : gain ternormalisasi

Spre : skor pretest

Spost : skor posttest

Smak : skor maksimum ideal

Selanjutnya untuk pengkategorian hasil penilaian pengetahuan dan sikap lingkungan peserta didik dapat menggunakan interval serta interpretasi indeks gain ternormalisasi yang telah dimodifikasi :

Tabel 2. Pengkategorian nilai gain

\begin{tabular}{cc}
\hline Interval Nilai Gain $(\mathrm{g})$ & Kategori \\
\hline$>0,70$ & Tinggi \\
$0.7>\mathrm{g}>0.3$ & Sedang \\
$<0.3$ & Rendah \\
\hline
\end{tabular}

(Hake, 1998)

\section{HASIL PENELITIAN DAN PEMBAHASAN}

\section{HASIL PENELITIAN}

Tahapan awal yang dilakukan dalam penelitian ini adalah dengan melakukan pengukuran awal (pre test) terhadap kemampuan peserta didik di kelas X 1 bidang keahlian agribisnis tanaman pangan dan hortikultura (ATPH) mengenai sikap dan pengetahuan lingkungan pada mata pelajaran fisika pokok bahasan usaha, energi, daya dan efisiensi. Pengukuran dan penilaian ini dilakukan untuk mengetahui sampai sejauhmana mana kemampuan sikap dan pengetahuan lingkungan peserta didik sebelum penggunaan atau pemanfaatan bahan ajar berwawasan lingkungan pada pokok bahasan tersebut. Data yang diperoleh pada pengukuran awal (pre test) akan dibandingkan dengan data pengukuran setelah adanya perlakuan (treatment) selanjutnya akan dianalisis sampai sejauh mana pengaruh terhadap peningkatan pengetahuan dan sikap lingkungan peserta didik.

\section{a.Sikap Lingkungan Peserta Didik}

Penilaian sikap belajar siswa diperoleh dari kuesioner yang berisi pertanyaan sebanyak 20 butir soal dengan 5 (lima) pilihan jawaban tentang sikap lingkungan siswa kelas X 1 bidang keahlian agribisnis tanaman pangan dan hortikultura (ATPH) Penilaian atau pengukuran dilakukan sebelum dan sesudah pembelajaran dengan menggunakan bahan ajar berwawasan lingkungan . Setiap siswa diminta 
menjawab pertanyaan yang ada pada kuesioner kemudian setiap jawaban yang diberikan skor berdasarkan skala likert yang menggunakan skala 5, baik itu pernyataan yang bersifat positif maupun yang negatif terhadap proses pembelajaran fisika materi atau pokok bahasan tentang usaha, energi, daya dan efisiensi sebelum dan sesudah menggunakan bahan ajar yang berwawasan lingkungan.

Penilaian untuk mengetahui pengaruh yaitu peningkatan sikap lingkungan peserta didik sebelum dan sesudah perlakukan (treatment), dapat dilihat melalui tabel analisis kuesioner sebagai berikut:

Tabel 3. Hasil Analisis Kuesioner Sikap Lingkungan Siswa Pre Tes dan Post Test

\begin{tabular}{cccc}
\hline No & Hasil Kuesioner & Pre Test & Post Test \\
\hline 1 & Skor tertinggi & 70.0 & 86.0 \\
\hline 2 & Skor terendah & 44.0 & 62.0 \\
\hline 3 & Skor rata-rata & 56.8 & 73.8 \\
\hline 4 & Jumlah Skor & 2046 & 2655 \\
5 & Standar Deviasi & 6.8 & 5.9 \\
\hline
\end{tabular}

Data tersebut diatas mengambarkan hasil analisis kuesioner siswa yang digunakan untuk mengetahui tanggapan sikap lingkungan peserta didik terhadap materi pelajaran fisika pokok bahasan usaha, energi, daya dan efisiensi pada tes awal (pre test) dan tes akhir (post test) yang memperlihatkan skor tertinggi, skor terendah dan skor rata-rata yang diperoleh siswa baik pada saat sebelum dan sesudah sebelum perlakuan.

Berdasarkan penilaian sikap lingkungan peserta didik sebelum dilakukan perlakukan (treatment) di peroleh data skor tertinggi yang diperoleh peserta didik adalah 70 dan skor terendah sebesar 44 kemudian nilai perolehan rata-rata sebanyak 56.8 dengan satndar deviasi sebesar 6.8. Setelah penerapan pembelajaran dengan bahan ajar yang berwawasan lingkungan serta perubahan atau perbaikan dalam penyajian materi pembelajaran maka terjadi peningkatan hasil penilaian sikap lingkungan peserta didik jika dibandingkan sebelum perlakukan, diperoleh data hasil tes akhir nilai tertinggi yang didapatkan peserta didik adalah 86 dan skor terendah sebesar 62 kemudian nilai perolehan rata-rata sebanyak 73.8 dengan standar deviasi sebesar 5.9. Berdasarkan hasil tersebut ratarata indeks $\mathrm{N}$-gain sikap lingkungan peserta didik diperoleh sebesar 0.4 yang artinya peningkatan sikap lingkungan peserta didik setelah perlakukan (treatment) dalam pembelajaran berada atau tergolong sedang Secara lebih rinci hasil penilaian sikap lingkungan peserta didik dapat dijabarkan lebih lanjut melalui tabel Persentase Penilaian sikap lingkungan peserta didik sebelum dan sesudah perlakukan (treatment).

Tabel 4.Persentase Penilaian Sikap Lingkungan Siswa Sebelum (pre test) dan Sesudah Perlakuan (post test)

\begin{tabular}{|c|c|c|c|c|}
\hline \multirow[b]{2}{*}{ Kategori Sikap } & \multicolumn{2}{|c|}{ Pre Test } & \multicolumn{2}{|c|}{ Post Test } \\
\hline & $\begin{array}{l}\text { Jumlah } \\
\text { Siswa }\end{array}$ & Persentase $(\%)$ & $\begin{array}{c}\text { Jumlah } \\
\text { Siswa }\end{array}$ & $\begin{array}{c}\text { Persentase } \\
(\%)\end{array}$ \\
\hline Sangat tinggi & 0 & 0 & 4 & 11.2 \\
\hline Tinggi & 16 & 44.5 & 32 & 88.9 \\
\hline Rendah & 20 & 55.5 & 0 & 0 \\
\hline Sangat rendah & 0 & 0 & 0 & 0 \\
\hline Jumlah & 36 & 100 & 36 & 100 \\
\hline
\end{tabular}

Hal tersebut diatas membuktikan bahwa ada pengaruh penggunaan bahan ajar berwawasan lingungan pada mata pelajaran fisika pokok bahasan usaha, energi, daya dan efisiensi terhadap 


\section{Alamsyah, Pemanfaatan Bahan Ajar}

peningkatan nilai sikap lingkungan peserta didik. Peningkatan tersebut dapat digambarkan melalui grafik sebagai berikut :

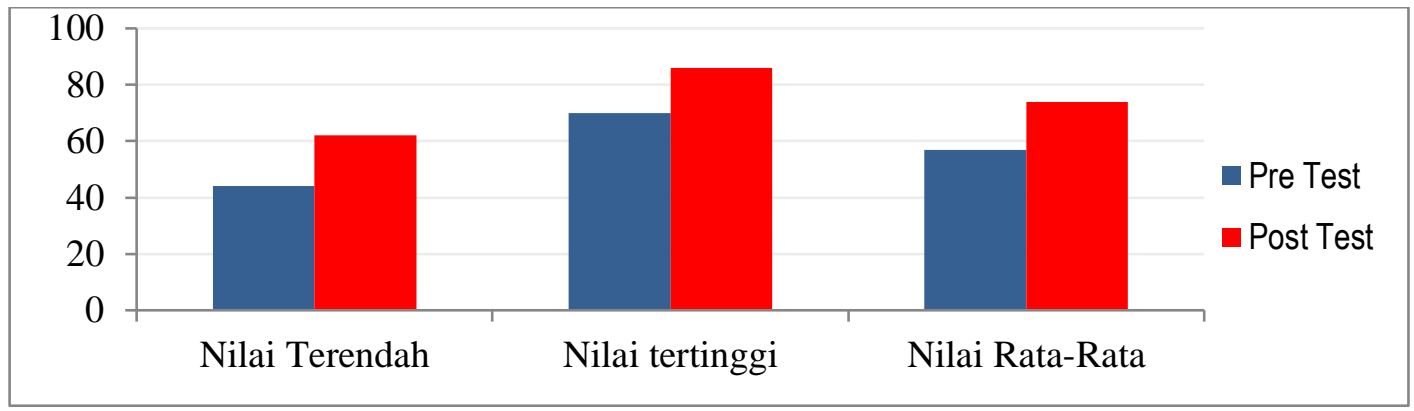

Gambar 1. Grafik peningkatan hasil penilaian sikap lingkungan siswa pada test awal (pre test) dan sesudah tes akhir (post test)

\section{b.Pengetahuan Lingkungan Peserta Didik}

Penilaian pengetahuan lingkungan peserta didik materi pelajaran fisika pokok bahasan usaha, energi, daya dan efisiensi sebelum dan sesudah menggunakan bahan ajar yang berwawasan lingkungan dilakukan dengan melakukan tes. Siswa diberikan soal dalam bentuk pilihan dengan 2 opsi, benar atau salah (true or false) sebanyak 20 butir. Tes untuk mengetahui pengetahuan lingkungan peserta didik dilakukan saat sebelum perlakuan (pre test) dan pada akhir setelah perlakuan (post test) . Hal tersebut dilakukan untuk mengetahui peningkatan pengetahuan lingkungan peserta didik sebelum tindakan dan sesudah pemanfaatan bahan ajar berwawasan lingkungan dalam proses pembelajaran.

Setelah dilakukan tes dan analisis data diperoleh hasil penilaian pengetahuan lingkungan peserta didik seperti disajikan pada Tabel 5 berikut.

Tabel 5. Data Hasil Penilaian Pengetahuan Lingkungan Siswa Pre Tes dan Post Test

\begin{tabular}{lcc}
\hline \multicolumn{1}{c}{ Komponen Statistik } & Pre Test & Post Test \\
\hline Subjek & 36 & 36 \\
Rata-rata & 66.0 & 77.1 \\
Median & 67.5 & 85.0 \\
Modus & 50.0 & 85.0 \\
Standar deviasi & 11.5 & 6.2 \\
Varians & 131.6 & 38.3 \\
Rentang & 35.0 & 20.0 \\
Nilai Terendah & 50.00 & 75.0 \\
Nilai Tertinggi & 85.00 & 95.0 \\
\hline
\end{tabular}

Proses pembelajaran setelah perlakuan (treatment) klasikal hasil penilaian pengetahuan lingkungan peserta didik meningkat dibandingkan kondisi awal sebelum perlakukan. Berdasarkan perhitungan dan analisis data pengetahuan lingkungan peserta didik sebelum dilakukan perlakukan (treatment) di peroleh data skor tertinggi yang diperoleh peserta didik adalah 85 dan skor terendah sebesar 50 kemudian nilai perolehan rata-rata sebanyak 66 dengan satndar deviasi sebesar 11.5. Setelah penerapan pembelajaran dengan memanfaatkan bahan ajar yang berwawasan lingkungan serta upaya integratif penanaman nilai-nilai etika dan konsep lingkungan hidup dalam penyajian materi pembelajaran maka terjadi peningkatan hasil penilaian pengetahuan lingkungan peserta didik jika dibandingkan sebelum perlakukan, diperoleh data hasil tes akhir nilai tertinggi yang didapatkan 
peserta didik adalah 95 dan skor terendah sebesar 75 kemudian nilai perolehan rata-rata sebanyak 77.1 dengan standar deviasi sebesar 6.2.

Berdasark hasil tersebut, selanjutnya diadakan penghitungan rata-rata indeks $\mathrm{N}$-gain pengetahuan lingkungan peserta didik diperoleh hasil sebesar 0.5 yang kemudian diartikan peningkatan pengetahuan lingkungan peserta didik setelah perlakukan (treatment) dalam pembelajaran berada atau tergolong sedang. Peningkatan pengetahuan lingkungan peserta didik pada materi pelajaran fisika pokok bahasan usaha, energi, daya dan efisiensi sebelum tindakan dan sesudah perlakukan dapat dilihat dalam grafik berikut ini:

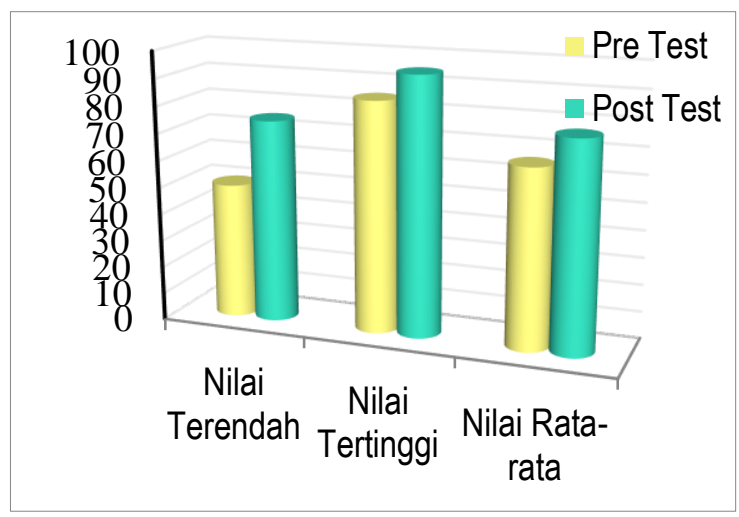

Gambar 2. Grafik peningkatan hasil penilaian pengetahuan lingkungan siswa pada test awal (pre test) dan sesudah tes akhir (post test)

\section{Pembahasan}

Pembahasan hasil penelitian ini berdasarkan hasil penilaian sikap dan pengetahuan lingkungan peserta didik terhadap materi pelajaran fisika pokok bahasan usaha, energi, daya dan efisiensi sebelum dan sesudah penggunaan bahan ajar berwawasan lingkungan dalam proses pembelajaran. Setelah bahan ajar mata pelajaran fisika disusun dengan memadukan nilai, konsep, teori, wawasan tentang lingkungan, upaya pelestarian keberadaan atau keberlanjutan komponen lingkungan khusunya yang berhubungan dengan usaha, energi, daya dan efisiensi selanjutnya diberikan sebagai bahan pelajaran kepada peserta didik pada kelas X 1 bidang keahlian agribisnis tanaman pangan dan hortikultura (ATPH). Sebelum penyajian materi pelajaran dengan bahan ajar berwawasan lingkungan diadakan tes awal untuk mengetahui kemampuan sikap dan pengetahuan peserta didik kemudian pada akhir materi pokok bahasan tersebut diadakan tes akhir dengan instrumen yang sama untuk mengukur perubahan nilai sikap dan pengetahuan peserta didik setelah mendapatkan materi pelajaran dari bahan ajar yang diberikan.

Hasil tes mengacu pada perolehan skor yang dicapai peserta didk dalam tes evaluasi hasil belajar baik sebelum dan sesudah perlakukan. Peningkatan sikap lingkungan peserta didk dari sebelum dan sesudah perlakuan (treatment), pada Tabel 3 diperoleh data bahwa rata-rata skor penilaian sikap lingkungan peserta didik secara klasikal sebelum perlakuan adalah 56.8. Setelah diadakan penelitian dengan penggunaan bahan ajar berwawasan lingkungan diperoleh rata-rata skor sikap lingkungan peserta didik siswa mencapai 73.8 dan diperoleh indeks $\mathrm{N}-$ Gain sebesar 0.4 yang menjelaskan peningkatan penilaian sikap lingkungan peserta didik setelah perlakuan (treatment) dalam pembelajaran tergolong sedang.

Data hasil penilaian sikap belajar siswa dapat menjelaskan bahwa rata-rata skor sikap lingkungan peserta didik siswa secara klasikal mengalami peningkatan setelah penggunaan bahan ajar berwawasan lingkungan. Dengan adanya peningkatan tersebut menunjukkan bahwa pembelajaran dengan menggunakan bahan ajar berwawasan lingkungan, yang mengintegrasikan antara materi pelajaran fisika pokok bahasan usaha, energi, daya dan efisiemnsi dengan konsep, nilai, etika, kearifan serta wawasan pengetahuan linkungan hidup dan pelestarianya. Peningkatan tersebut diakibatkan oleh adanya internalisasi konsep, nilai, konteks yang berhubungan tentang pentingnya keberadaan lingkungan dalam mendukung usaha (aktivitas manusia), penyediaan energi berkelanjutan, serta upaya efisiensi yang berdampak pada kemampuan daya manusia dan komponen lainya dalam kehidupan di 


\section{Alamsyah, Pemanfaatan Bahan Ajar}

lingkungan. Hal-hal tersebut secara konseptual integratif tercantum dalam bahan ajar yang disajikan kepada peserta didik sehingga memberikan dampak pada konstruksi berpikir peserta didik bahwa konsep ilmu fisika sesuai dengan pokok bahasan terkait sangat erat kaitannya dengan dukungan lingkungan dengan segala fenomena yang terjadi didalamnya dan keberlanjutaaanya sangat tergantung pada upaya proteksi atau kelestarian lingkungan hidup. Pemahaman-pemahaman tersebut tersebut ternyata mampu membangun kecenderungan berpikir peserta untuk semakin paham dan peduli dengan kelestarian atau keberlanjutan lingkungan dalam penyediaan energi serta mendukung usaha dan daya komponen kehidupan, tentu saja hal tersebut berdampak langsung terhadap meningkatnya sikap lingkungan peserta didik dalam pembelajaran.

Aspek pengetahuan lingkungan peserta didik dapat juga dilihat peningkatannya dalam pembahasan ini. Berdasarkan data pada tabel 5 diperoleh data bahwa rata-rata skor penilaian pengetahuan lingkungan peserta didik secara klasikal sebelum perlakuan (treatment) adalah 66 Setelah diadakan perubahan dalam pembelajaran dengan penggunaan bahan ajar berwawasan lingkungan diperoleh rata-rata skor pengetahuan lingkungan peserta didik siswa mencapai 77.1 kemudian setelah perhitungan diperoleh indeks $\mathrm{N}$-Gain sebesar 0.5 yang menyatakan peningkatan penilaian pengetahuan lingkungan peserta didik setelah perlakuan (treatment) dalam pembelajaran tergolong sedang.

Pembelajaran mata pelajaran fisika pada pokok bahasan usaha, energi, daya dan efisiensi dengan menggunakan bahan ajar berwawasan lingkungan telah memberikan pemahaman kepada peserta didik tentang konsep teori fisika yang dengan pokok bahasan tersebut yang terintegrasi dengan konstruksi pengetahuan, konsep, teori dan konteks wawasan pendidikan lingkungan hidup. Hal tersebut telah memungkinkan adanaya pemahaman dari segi wawasan pengetahuan peserta didik bahwa keberadaan dan kondisi lingkungan yang ada saat ini maupun keberlanjutannya sangat menentukan terhadap segala aktivitas (usaha), penyediaaan energi bagi kehidupan, dan kemampuan daya serta efisiensi komponen-komponen kehidupan yang ada dilingkungan.

Pengetahuan tersebut menimbulkan pemahaman bukan hanya tentang teori, konsep ilmu fisika, tetapi peserta didik juga telah mampu memahami bahwa keberadaan aktivitas (usaha), energi, daya dan efisiensi bagi manusia dan komponen kehidupan lainnya sangat erat bahkan menyatu dengan keberadaan, kondisi lingkungan yang ada sekarang dan keberlajutaannya. Konstruksi pemikiran peserta didik yang menyatukan antara ilmu dasar fisika dan nilai, etika,pengetahuan lingkungan hidup secara utuh telah dapat membuktikan adanya peningkatan penilaian pengetahuan lingkungan peserta didik ..

\section{KESIMPULAN}

Berdasarkan hasil penelitian dan pembahasan di atas, maka dapat diperoleh kesimpulanya bahwa Penggunaan bahan ajar berwawasan lingkungan dapat meningkatkan sikap lingkungan peserta didik kelas X 1 bidang keahlian agribisnis tanaman pangan dan hortikultura (ATPH) SMK Negeri 4 Jeneponto terhadap materi pelajaran fisika pokok bahasan usaha, energi, daya dan efisiensi dari sebelum perlakuan (treatment) dilaksanakan. Nilai-nilai rata-rata penilaian sikap lingkungan peserta didik siswa secara klasikal setelah perlakuan (treatment) dilakukan mencapai 73.8 kemudian setelah diihitung indeks $\mathrm{N}$-Gain diperoleh hasil 0.4 yang membuktikan peningkatan sikap lingkungan peserta didik sesudah perlakuan dalam pembelajaran tergolong sedang.

Penggunaan bahan ajar berwawasan lingkungan juga telah meningkatkan pengetahuan lingkungan peserta didik kelas $\mathrm{X} 1$ bidang keahlian agribisnis tanaman pangan dan hortikultura (ATPH) SMK Negeri 4 Jeneponto terhadap materi pelajaran fisika pokok bahasan usaha, energi, daya dan efisiensi dari sebelum perlakuan (treatment) dilakukan. Nilai-nilai rata-rata penilaian pengetahuan lingkungan peserta didik siswa secara klasikal setelah perlakuan (treatment) dilakukan mencapai 77.1 kemudian diperoleh indeks $\mathrm{N}$-Gain sebesar 0.5 yang menyatakan peningkatan pengetahuan lingkungan peserta didik sesudah perlakuan dalam pembelajaran berkategori sedang. 
UNM Environmental Journals, Vol. 2 No. 2 April hal. 28-33

\section{Referensi}

Arifuddin, M., Salam, M., dan Shofa Mawaddah. 2017. Pengembangan Bahan Ajar Berwawasan Lingkungan Bantaran Sungai Untuk Melatihkan Kemampuan 5 M. Jurnal Sains dan Pendidikan Fisika (JSPF) Jilid 13 Hal: 248-254 Nomor 1. April 2017 FKIP ULM

Depdiknas. 2003. Pedoman Khusus Pengembangan Silabus Berbasis Kompetensi Sekolah Menengah Kejuruan (SMK). Jakarta.

Gulo. 2002. Strategi Belajar Mengajar. Jakarta: Grasindo

Hake, R. R. (1998). Interactive-engagement vs traditional methods: A six-thousand student survey of Mechanics test data for introductory physics courses. American Journal of physics, 66(1), 6474.

Hamalik, O. 2005. Proses Belajar Mengajar. Jakarta: Bumi Aksara.

Ibrahim, M. 2010. Dasar-Dasar Proses Belajar Mengajar. Surabaya: Unesa University Press.

Pemendikbud Nomor 103 Tahun 2014 tentang Pembelajaran Pada Pendidikan Dasar dan Pendidikan Menengah. Jakarta. 